\title{
IDENTIFIKASI PROFIL DASAR LAUT MENGGUNAKAN INSTRUMEN SIDE SCAN SONAR DENGAN METODE BEAM PATTERN DISCRETE-EQUI-SPACED UNSHADED LINE ARRAY
}

\section{IDENTIFICATION OF SEABED PROFILE USING SIDE SCAN SONAR INSTRUMENT WITH PATTERN DISCRETE-EQUI-SPACED UNSHADED LINE ARRAY METHOD}

\author{
Muhammad Zainuddin Lubis*, Wenang Anurogo \\ Program Studi Teknik Geomatika Jurusan Teknik Informatika, Politeknik Negeri Batam \\ Jalan Ahmad Yani, Batam Centre, Batam 29461, Indonesia. \\ *Corresponding author e-mail: zainuddinlubis@polibatam.ac.id
}

Submitted: 23 Februari 2017 / Revised: 21 April 2017 / Accepted: 26 April 2017

http://doi.org/10.21107/jk.v10i1.2563

\begin{abstract}
Riau Islands is an island that has a variety of habitat objects, and forms of submarine structures that have a very high ocean dynamics, Punggur Sea is the sea which was a sea of Riau Island in Indonesia. Side scan sonar (SSS) is an instrument based on sonar system wich capable of showing the image of two-dimensional surface of the seabed with contour conditions, topography, and the underwater target simultaneously. Beam Pattern Discrete-equispaced unshaded Line Array Method is used to compute the two-dimensional beam pattern which depends on the angle of the incoming sound waves from the axis of the array are acceptable depending on the angle at which the sound beam array. This research was conducted in December 2016 in the sea Punggur, Batam, Riau Islands-Indonesia, with coordinate system $104^{\circ} 08,7102 \mathrm{E}$ and $1^{\circ} 03,2448 \mathrm{~N}$ until $1^{\circ} 03.3977 \mathrm{~N}$ and $104^{\circ} 08,8133 \mathrm{E}$, using Side Scan Sonar Tow C-Max CM2 fish instruments with a frequency of $325 \mathrm{kHz}$. The Results obtained from the recording there are 7 targets, and Beam pattern of Discrete-Beam method Equi-Spaced unshaded Line Array in targets 4 have the highest value in the Pattern is 21:08 dB directivity. The results of the model's beam pattern have anaxis value at the incidence angle $\left(^{\circ}\right.$ ) of the directivity pattern $(d B)$ are not on the value 0 or the central beam pattern generated on the target 6 with incident angle $-1.5^{\circ}$ and $1.5^{\circ}$ have declined by $-40 \mathrm{~dB}$. Characteristics of bottom sediment in the sea waters Punggur found more sand.Discrete-method result Beam EquiSpaced unshaded Line Array discovered the sunken wreck.
\end{abstract}

Keywords: Side Scan Sonar, Beam Pattern Discrete-Equi-Spaced Unshaded Line Array, Incidence angle, Directivity pattern

\section{ABSTRAK}

Kepulauan Riau adalah kepulauan yang memiliki berbagai objek habitat, dan bentuk struktur kapal selam yang memiliki dinamika samudra sangat tinggi, laut Punggur adalah laut yang merupakan bagian lautan di Kepulauan Riau, Indonesia. Side scansonar (SSS) merupakan instrumenpengembangan sistem sonar yang mampu menunjukkan dalamgambar dua dimensional permukaan dasar laut dengan kondisi kontur, topografi,dan target secara bersamaan. Metode Beam PatternDiscrete-Equi-Spaced Unshaded Line Array digunakan untuk menghitung pola pancaran gelombang dua dimensi yang tergantung pada sudut dari gelombang suara yang masuk dari sumbu array yang diterima tergantung pada sudut di mana sinar suara pada array. Penelitian ini dilakukan pada Desember 2016 di laut Punggur,Batam, Kepulauan Riau-Indonesia, dengan koordinat $104^{\circ}$ 08,7102 E dan $1^{\circ} 03,2448 \mathrm{~N}$ sampai $1^{\circ} 03.3977 \mathrm{~N}$ dan $104^{\circ} 08,8133 \mathrm{E}$, menggunakan instrumen Side Scan Sonar C-Max CM2 Tow fishdengan frekuensi $325 \mathrm{kHz}$. Hasil yang diperoleh dari perekaman terdapat 7 target, dan Beam pattern dari metode BeamDiscrete-Equi-Spaced Unshaded Line Array target 4 memiliki nilai tertinggi pada directivity Pattern yaitu $21.08 \mathrm{~dB}$. Hasil model beam pattern ini memiliki nilai pusat pada incidence angle $\left(^{\circ}\right)$ terhadap Directivity pattern 
(dB) tidak berada di nilai 0 ataupun pada pusat beam pattern yang dihasilkan pada target 6 dengan nilai incident angle $-1.5^{\circ}$ dan $1.5^{\circ}$ mengalami penurunan hingga $-40 \mathrm{~dB}$. Karakteristik sedimen dasar perairan di laut punggur ditemukan lebih banyak pasir. Hasil metode Beam Discrete-EquiSpaced Unshaded Line Array ditemukan bangkai kapal tenggelam.

Kata Kunci: Side Scan Sonar, Beam Pattern Discrete-Equi-Spaced Unshaded Line Array, Incidence angle, Directivity pattern

\section{PENDAHULUAN}

Laut Punggur merupakan laut yang terletak di Batam, Kepulauan Riau yang mempunyai beragam habitat objek, dan bentuk struktur bawah laut yang memiliki dinamika laut yang sangat tinggi. Laut punggur mengalami kerusakan ekosistem karang, lamun, dan habitat ikan yang sangat besar,yang disebabkan banyaknya benda atau objek di dasar laut yang menyebabkan hancurnya ekosistem laut (Bachtiar et al., 2012). Hidroakustik adalah teori tentang gelombang suara dan perambatannya dalam medium air. Metode hidroakustik merupakan salah satu metode yang pengoperasiannya mampu mendeteksi semua target yang ada di kolom perairan (Lubis dan Anurogo, 2016; Lubis et al., 2016). Selain itu juga, dapat dipergunakan dalam eksplorasi sumberdaya ikan demersal serta mendeteksi dasar perairan. Beberapa kelebihan metode ini adalah memiliki kecepatan dalam efisiensi pengambilan data dan memiliki tingkat akurasi yang tinggi terhadap data yang diperoleh, dan dapat digunakan pada perairan yang dalam dan luas, juga tidak merusak sumberdaya ikan (Lubis dan Pujiyati, 2016; Pujiyati et al., 2016). Laut batam dan kepulauan riau selalu mengalami pencemaran yang semakin meningkat setiap tahunnya, dan hal ini disebabkan dengan bnyaknya pencemaran material berat yang terdapat di dasar laut (Lubis et al., 2017)

Prinsip dasar awal dari sonar adalah menggunakan suara untuk mendeteksi atau menemukan objek yang secara khusus berada di laut (Hansen, 2011). Side scan sonar adalah instrumen yang digunakan dalam survei untukmelakukan pencitraan dasar laut. Side scan sonar (SSS) merupakan pengembangan sonar yang mampu menunjukkan dalamgambar dua dimensional permukaan dasar laut dengan kondisi kontur, topografi, dan target secara bersamaan. Instrumen ini mampu membedakan besar kecil partikel penyusun permukaan dasar laut seperti batuan, lumpur, pasir, kerikil, atau tipe-tipe dasar perairan lainnya (Bartholoma, 2006). SSS digunakan untuk berbagai kegunaan, seperti pendeteksian keberadaan pipa dan kabel laut, pendeteksian struktur dangkal dasar laut, pelaksanaan pengerukan, studi lingkungan, kemiliteran, arkeologi, perikanan, dan pertambangan (Manik, 2011).

Sonar adalah istilah umum untuk setiap instrumen yang menggunakan deteksi forremote suara benda bawah air (Haykin, 1985). Sistem sonar aktif akan menghasilkan ledakan singkat (ping) dari suara frekuensi tinggi. Gelombang akustik yang dibangkitkan dari transduser didalam kolom air dan dasar laut sehingga akan menghasilkan gema yang diukur dengan empat kuadran dalam transduser beam pattern (Manik, 2015) .

Untuk jenis sonar monostatic, yaitu sonar yang memiliki pemancar dan penerima, hasil dari pancaran pada transduser menggambarkan ketergantungan hambur balik (back scattering) pada sudut antara pusat gelombang akustik pada target (MacLennan dan Simmonds, 2008). Interpretasi secara kuantitatif adalah bertujuan untuk mendefenisikan hubungan antara posisi kapal, posisi towfish dan posisi objek sehingga diperoleh besaran horizontal dan besaran vertikal. Besaran horizontal yaitu nilai posisi objek ketika lintasan towfish sejajar dengan lintasan kapal maupun ketika lintasan dengan towfish membentuk sudut. Besaran vertical meliputi tinggi objek dari dasar laut serta kedalaman objek (Mahyuddin, 2008). Secara manual, geometri SSS dan perhitungannya diilustrasikan pada Gambar 1.

Penelitian ini bertujuan untuk menjawab permasalahan yang ada dilautan punggur, Batam, Kepri dengan cara melakukan identifikasi target dasar laut menggunakan instrument Side Scan Sonar (SSS) menggunakan metode Beam Pattern 
Discrete-Equi-Spaced Unshaded Line Array dan menerapkan ilmu hidroakustik.

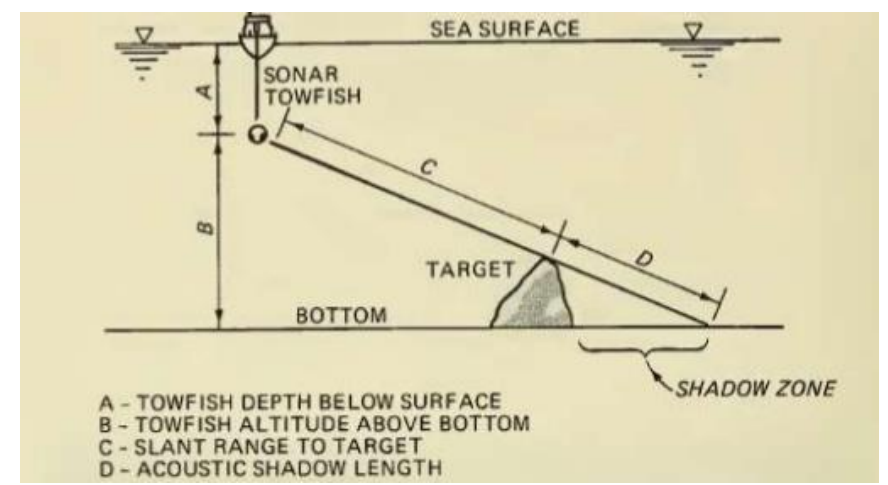

Gambar 1. Geometri dari side scan sonar

\section{MATERI DAN METODE}

Penelitian ini dilakukan pada tanggal 17 Desember 2016 di laut Punggur, Batam, Kepulauan Riau-Indonesia. Pada koordinat $104^{\circ} 08,7102 \mathrm{E}$ dan $1^{\circ} 03,2448 \mathrm{~N}$ sampai 1 - 03.3977N dan $104^{\circ} 08,8133$ E (Gambar 3).Penelitian memiliki 3 baris pelacakan (Gambar 2). Akuisisi data akustik dilakukan menggunakan instrumen Side Scan Sonar CMax CM2 Tow fish ditetapkan pada frekuensi (325 kHz) dan dengan jarak antar jalur pemeruman maksimum $200 \mathrm{~m}$ dan panjang kabel towing $25 \mathrm{~m}$, dengan kecepatan kapal 6-7 Knot (Gambar 2). Lokasi penelitian dapat dilihat pada Gambar 3, dan Karakteristik beam pattern C-Max CM2 Side Scan SonarTow fish dapat dilihat pada Gambar 4. Gambar 4, menjelaskan bagaimana pola sebaran pancaran gelombang yang diperoleh atau dilakukan menggunakan CM-2, C-MAX instrumen Side Scan Sonar (SSS) saat berada di daerah deteksi di laut.
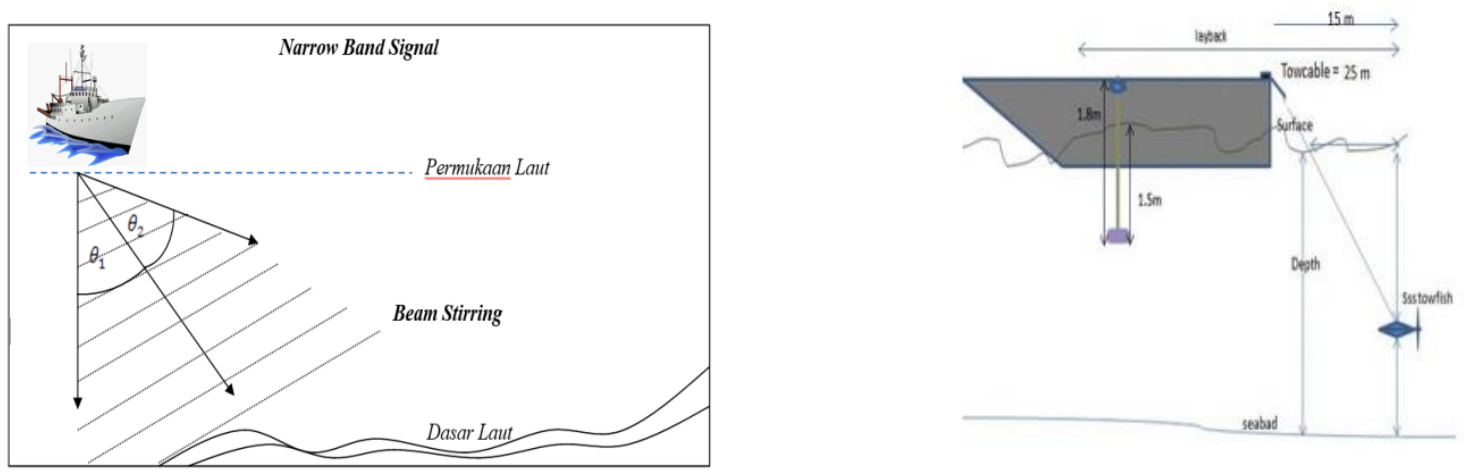

Gambar 2. Ilustrasi Perekaman data Side Scan Sonar 


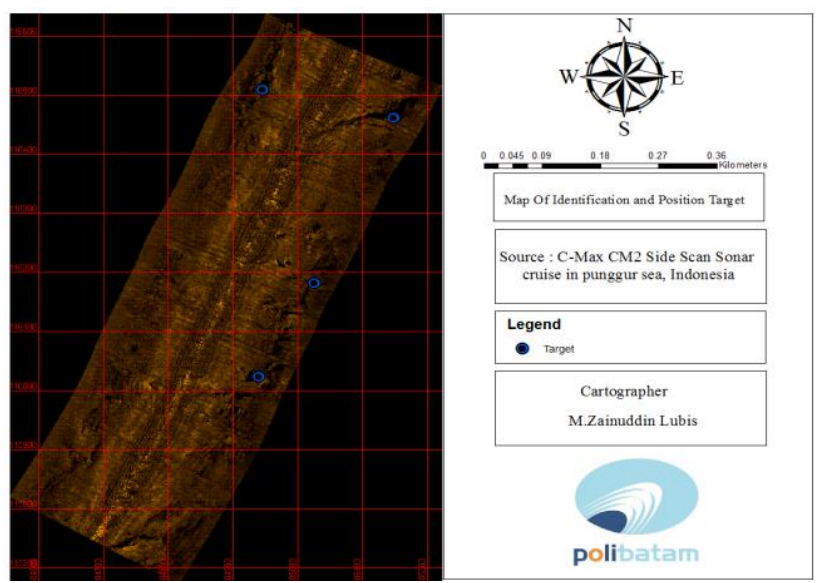

Gambar 3. Peta lokasi penelitian dan perekaman Side Scan Sonar (SSS)

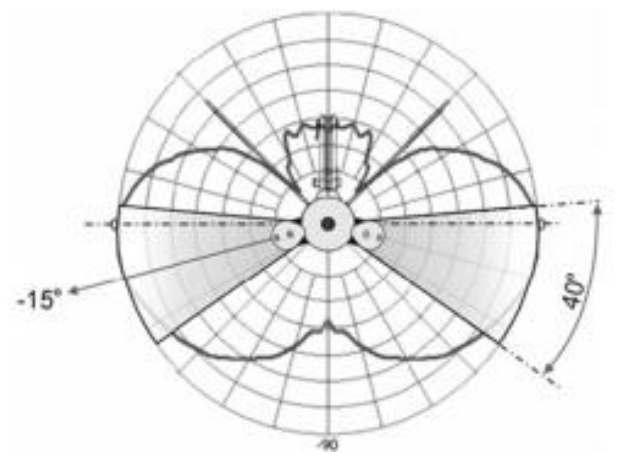

Gambar 4. Karakteristik beam pattern C-Max CM2 Side Scan SonarTow fish

\section{POLA BEAM DUA DIMENSI}

Menghitung beam pattern dua dimensi tergantung pada sudut dari gelombang suara yang masuk dari sumbu array, daya yang diterima tergantung pada sudut di mana sinar suara insiden pada array. Kami bisa menggambarkan ketergantungan sudut ini dengan satu persamaan untuk berhubungan kekuatan aktual yang diterima untuk waktu rata-rata daya pada poros (di mana. $\theta=0^{\circ}$ dan daya maksimum adalah a) Rasio ini adalah fungsi beam pattern dua dimensi dari array, b $(\theta)$ di mana:

$$
\begin{aligned}
& b(\theta)=\frac{\langle P(\theta)\rangle}{\left\langle P\left(\theta=0^{\circ}\right)\right\rangle}=\frac{\frac{\left(M p_{\max }\right)^{2}}{R}(1+\cos \delta)}{\frac{\left(M p_{\max }\right)^{2}}{R}\left(1+\cos 0^{\circ}\right)} \\
& b(\theta)=\frac{\frac{\left(M p_{\max }\right)^{2}}{R}(1+\cos (k d \sin \theta))}{2 \frac{\left(M p_{\max }\right)^{2}}{R}}=\frac{(1+\cos (k d \sin \theta))}{2}
\end{aligned}
$$

Menggunakan sebuah identifikasi geometridi dalam sistem sonar adalah : 


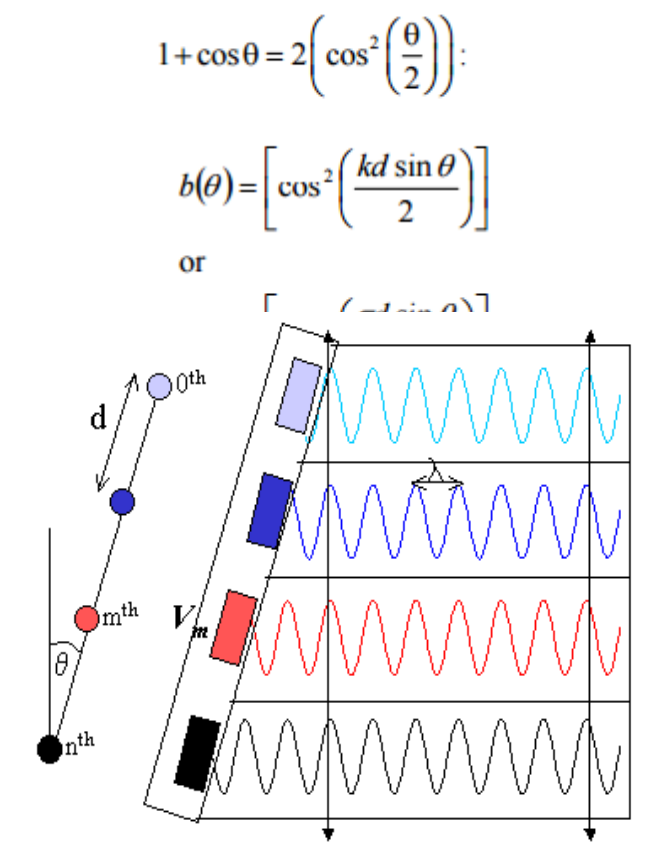

Geam 5attern Discrete-Equi-Spaced Unshaded Line Array

$$
b(\theta)=\left(\frac{V}{n}\right)^{2}=\left[\frac{\sin \left(\frac{n \pi d}{\lambda} \sin \theta\right)}{n \sin \left(\frac{\pi d}{\lambda} \sin \theta\right)}\right]^{2}
$$

\section{HASIL DAN PEMBAHASAN}

Hasil pencitraaan dasar perairan pada laut Punggur yang merupakan bagian dari kepulauan Riau, Indonesia, dengan menggunakan instrumen Side Scan Sonar (SSS) memiliki hasil pencitraan dasar laut yang memiliki berbagai bentuk hasil deteksi. Pada dasar perairan yang terdeteksi merupakan bentuk lereng, yang umumnya bagian pada atas akan terisi oleh sedimen berbutir halus, dan bagian bawah akan terisi oleh sedimen berbutir kasar karena pengaruh gaya gravitasi. Berdasarkan citra side scan sonar dapat terlihat dengan jelas perbedaan tekstur dan kekasaran pada sedimen pasir, pasir biogenik dan lumpur. Terdapat 7 target yang dideteksi oleh citra hasil perekaman Side Scan Sonar menggunakan C-MAX dengan estimasi deteksi target terdapat sebuah benda besar yang dilihat dari visual gambar pada target 6 di koordinat $1^{\circ} 03.3101 \mathrm{~N}$ dan $104^{\circ} 08.7362 \mathrm{E}$ (Gambar 6 ). Benda ini dapat di duga adalah bangkai kapal yang tenggelam di dasar laut Punggur, Batam, Kepri Indonesia. Hasil perolehan waktu, Posisi ping, Gain dan ketinggian dari perekaman SSS dapat dilihat pada Tabel 1. Hasil citra dasar laut dapat dilihat pada Gambar 5. 
Tabel 1. Target, Waktu, Posisi, Ping , Gain dan Tinggi

\begin{tabular}{ccccccc}
\hline Target & Waktu & Latitude & Longitude & Ping & $\begin{array}{c}\text { Gain } \\
(\mathbf{d B})\end{array}$ & $\begin{array}{c}\text { Tinggi } \\
(\mathbf{m})\end{array}$ \\
\hline 1 & $13: 43: 12 \mathrm{AM}$ & $1^{\circ} 03.2448 \mathrm{~N}$ & $104^{\circ} 08.7102 \mathrm{E}$ & 417 & 3 & 13.8 \\
2 & $13: 43: 20 \mathrm{AM}$ & $1^{\circ} 03.2109 \mathrm{~N}$ & $104^{\circ} 08.8057 \mathrm{E}$ & 458 & 1 & 14.5 \\
3 & $13: 44: 05 \mathrm{AM}$ & $1^{\circ} 03.2992 \mathrm{~N}$ & $104^{\circ} 08.7471 \mathrm{E}$ & 678 & 4 & 14.5 \\
4 & $13: 42: 56 \mathrm{AM}$ & $1^{\circ} 03.2207 \mathrm{~N}$ & $104^{\circ} 08.7180 \mathrm{E}$ & 339 & 5 & 17.8 \\
5 & $13: 44: 57 \mathrm{AM}$ & $1^{\circ} 03.3977 \mathrm{~N}$ & $104^{\circ} 08.8133 \mathrm{E}$ & 931 & 2 & 13.8 \\
6 & $13: 44: 11 \mathrm{AM}$ & $1^{\circ} 03.3101 \mathrm{~N}$ & $104^{\circ} 08.7362 \mathrm{E}$ & 705 & 6 & 18.1 \\
7 & $13: 42: 53 \mathrm{AM}$ & $1^{\circ} 03.1832 \mathrm{~N}$ & $104^{\circ} 08.7875 \mathrm{E}$ & 331 & 3 & 14.8 \\
\hline
\end{tabular}

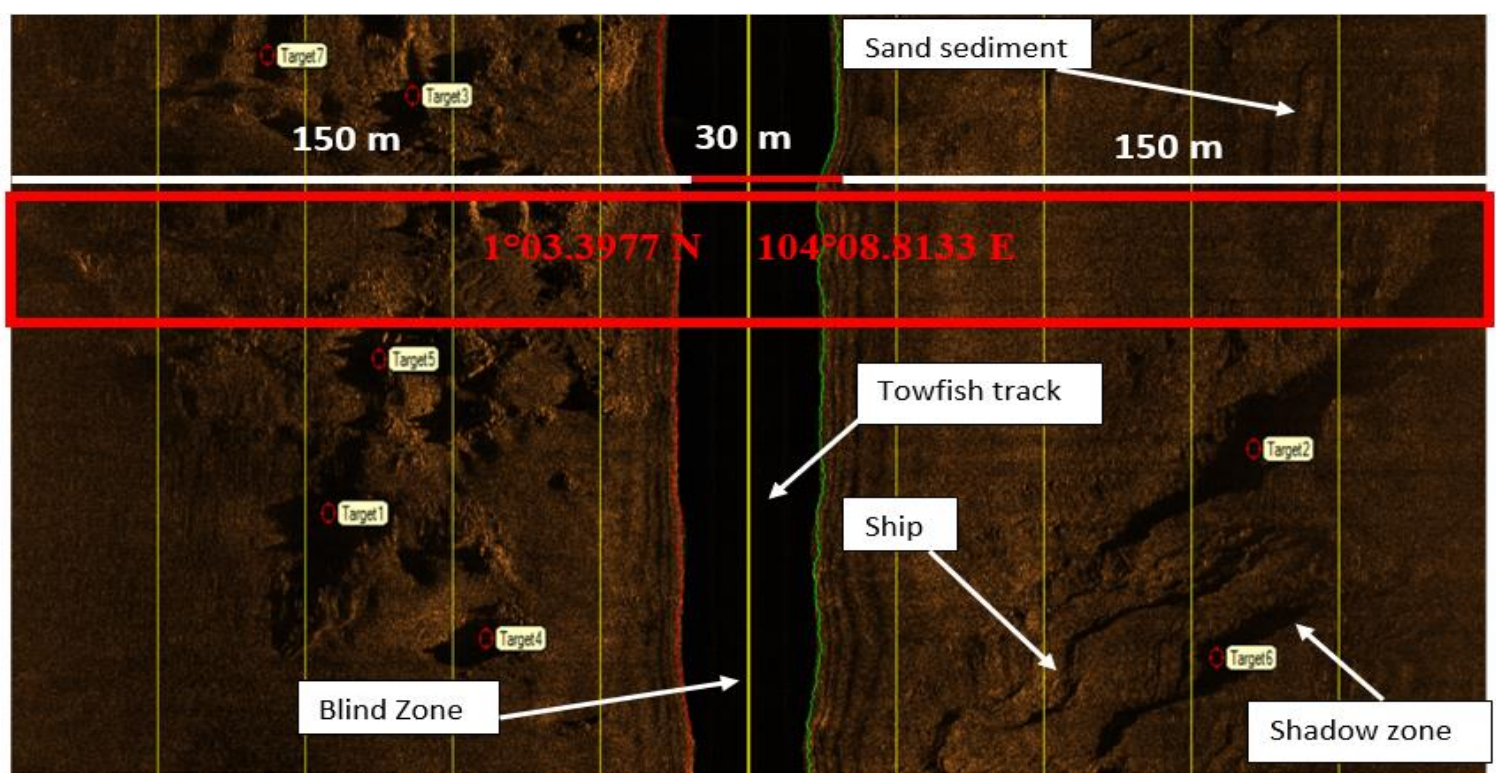

Gambar 6. Klasifikasi sedimen dasar laut di laut punggur

Terdapat garis-garis pada citra sedimen, diduga karena pengaruh pergerakan kapal dan pergerakan tow vehicle sehingga mengganggu tampilan pada citra (Gambar 7). Laut punggur merupakan perairan yang berarus karena adanya pengaruh dari arus laut yang bersifat fisis. Hal ini menyebabkan pergerakan tow vehicle lebih sulit untuk dikendalikan. Berdasarkan data pergerakan side scan sonar ditemukan gerakan pitch pada sensor terjadi hingga 15 derajat dari posisi diam 0 derajat gerakan roll terjadi hingga 10 derajat dari posisi saat diam 0 derajat. 

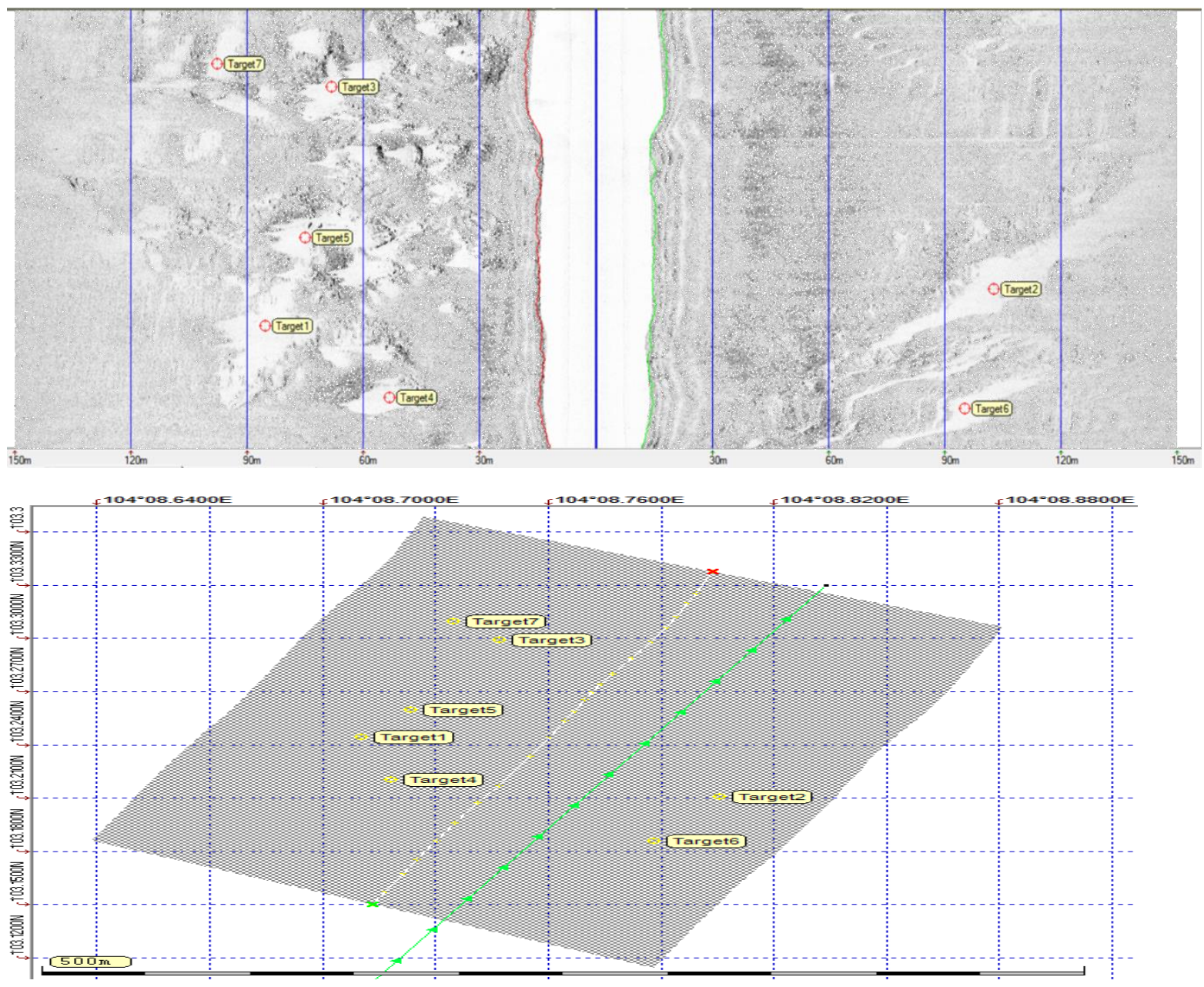

Gambar 7. Posisi target dan citra dasar laut (SSS)

Gambar 7 menunjukan citra sedimen permukaan dasar laut yang memiliki target sejbanyak 7 objek. Target 6 merupakan objek kapal yang tenggelam di dasar laut, sedangkan objek berupa pasir dapat terlihat dengan jelas, yaitu pada target 5. Objek kapal ditemukan pada koordinat $1^{\circ} 03.3101 \mathrm{~N}$ and $104^{\circ} 08.7362$ E. Pada bagian (sisi kanan) terlihat adanya bentuk materialyang berwarna lebih terang. Adanya galian menyebabkan perbedaan tekstur, kekasaran dan kemiringan sedimen dasar laut. Selain itu galian yang terjadi di dasar laut diduga menyebabkan sedimen yang lebih kasar dengan ukuran butir partikel lebih besar dibawahnya terangkat keatas. Menurut Urick (1983) ukuran butir, skala kekasaran permukaan sedimen dan variasi kemiringan yang signifikan dapat menjadi peran penting dalam respon akustik.

Minarto et al. (2008) menyatakan arus yang deras akan mengendapkan butiran sedimen yang kasar dan arus yang lemah akan mengendapkan sedimen berbutir halus. Sedangkan bentuk dasar perairan akan berpengaruh terhadap letak sedimen. Menurut Kenny et al., (2003) sapuan side scan sonar dapat menghasilkan mosaik, geologi dan fitur sedimentologis yang mudah dikenali dan diinterpretasi secara kualitatif sehingga dapat memberikan informasi tentang dinamika dasar laut. 

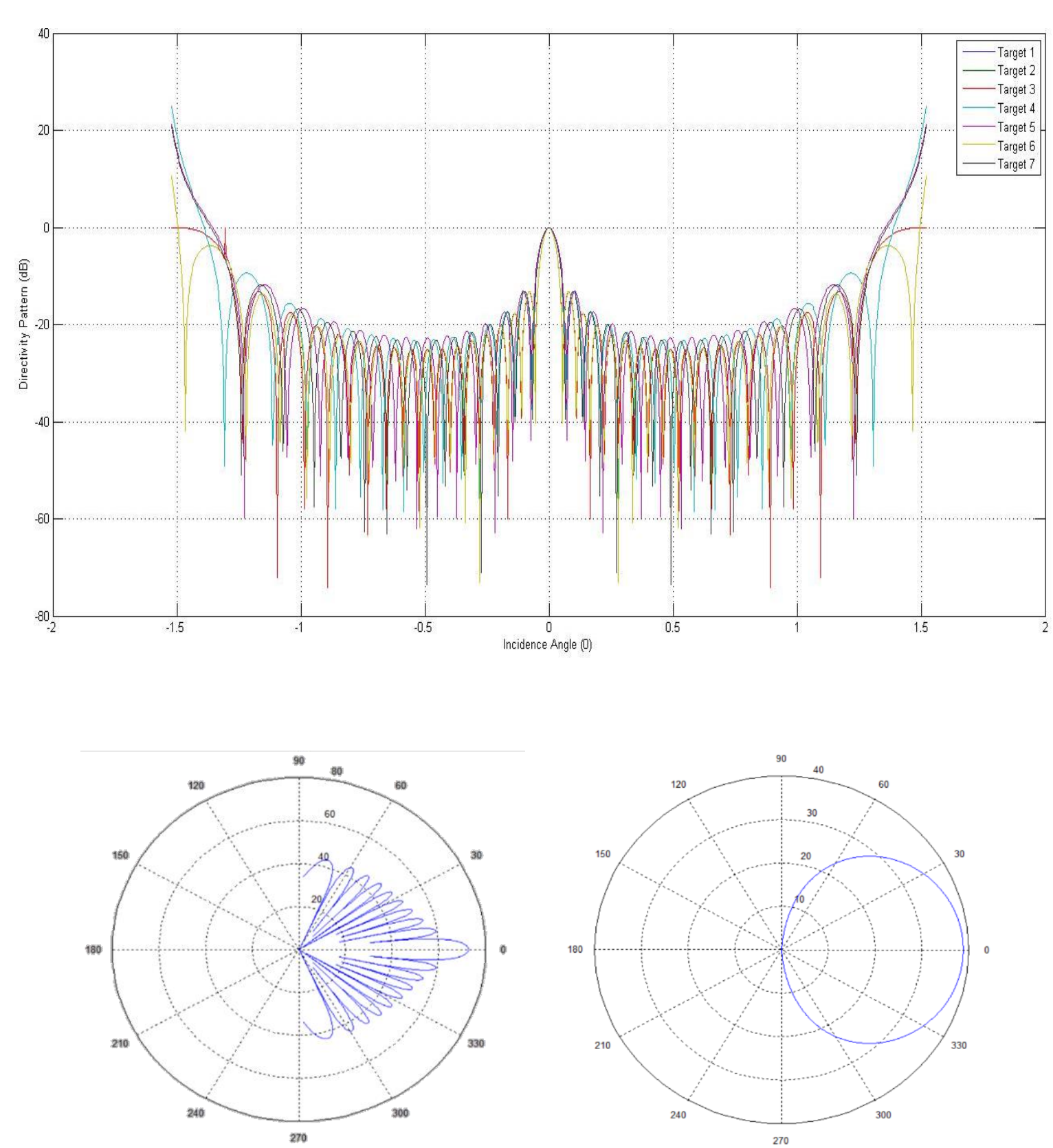

Gambar 8. Beam pattern incidence angle $\left(^{\circ}\right)$ terhadap Directivity pattern $(\mathrm{dB})$ dan Pola Beam

Pada Gambar 8 menunjukkan hasil banyaknya target yang diperoleh dengan 7 target terhadap pola pancaran dari metode Discrete-Equi-Spaced Unshaded Line Array target 4 memiliki nilai tertinggi pada Directivity Pattern yaitu $21.08 \mathrm{~dB}$ yang ditunjukkan dengan warna biru muda. Dengan melihat pusat pada hasil model beam pattern ini target 6 memiliki nilai pusat pada incidence angle $\left({ }^{\circ}\right)$ terhadap Directivity pattern $(\mathrm{dB})$ tidak berada di nilai 0 ataupun pada pusat beam pattern yang dihasilkan. Pada target 6 terdapat nilai incident angle $-1.5^{\circ}$ dan $1.5^{\circ}$ mengalami penurunan hingga $-40 \mathrm{~dB}$. Hal ini dapat dilihat hubungannya dengan nilai altitude $(\mathrm{m})$ yang bernilai $18.1 \mathrm{~m}$ dan gain 6 $\mathrm{dB}$ yang diduga merupakan objek kapal karam yang berada di dasar laut. Pada target 4 terdapat nilai incident angle $\left(^{\circ}\right)-1.32^{\circ}$ dan $1.32^{\circ}$ mengalami penurunan hingga $-50 \mathrm{~dB}$. Dekonvulusion hasil metode ini menunjukkan pola beam yang masih terpusat dengan menyentuh 2 kuadran dari sinyal berada, hasil ini memberikan kesamaan pola beam dan beam Pattern yang dihasilkan dengan melihat nilai panjang gelombang dan 
frekuensi yang dihasilkan (Jain dan Makris, 2016). Hal ini dapat dilihat hubungannya dengan nilai altitude $(\mathrm{m})$ yang bernilai 17.8 dan nilai gain $5 \mathrm{~dB}$ yang diduga merupakan objek kapal karam yang berada di dasar laut.

\section{KESIMPULAN DAN SARAN}

Penelitian di Laut Punggur, Batam dengan CMax CM2 Side Scan SonarTow fish pada frekuensi $325 \mathrm{kHz}$, pada hasil identifikasi dan pengungkapan hasil dasar laut Punggur, Batam, Indonesia menunjukkan hasil deteksi pada sedimen dasar perairan lebih banyak pasir yang memiliki nilai gain dan altitude yang tinggi. Hasil perekaman citra side scan sonar (SSS) mengidentifikasi 7 target, sedangkan pada target 4 dan 6 dengan hasil metode Discrete-Equi-Spaced Unshaded Line Array ditemukan bangkai kapal tenggelam. Hal ini menunjukkan adanya hubungan yang tegak lurus antara incident angle $\left({ }^{\circ}\right)$, Directivity pattern $(d B)$, Altitude $(m)$, dan Nilai gain (dB). Metode Discrete-EquiSpaced Unshaded Line Array merupakan metode yang dapat digunakan untuk melakukan identifikasi target dasar laut, dan metode ini merupakan metode yang memiliki kelebihan yang dapat menampilkan hubungan antara pancaran dengan hasil deteksi yang didapat.

\section{UCAPAN TERIMA KASIH}

Penulis berterimakasih kepada pihak Politeknik Negeri Batam, Marine Instrument and Application Club (MIAC), Pihak PT Geotronix Indonesia, Rekan-rekan dosen Teknik Geomatika, dan dan semua pihak yang membantu dalam pelaksanaan penelitian ini.

\section{DAFTAR PUSTAKA}

Bachtiar, I., Damar, A., \& Zamani, N. P. (2012). Assessing Ecological Resilience of Indonesian Coral Reefs. Journal of Coastal Development, 14(3), 214-222.

Bartholomä, A. (2006). Acoustic bottom detection and seabed classification in the German Bight, southern North Sea. Geo-Marine Letters, 26(3), 177.

Jain, A. D., \& Makris, N. C. (2016). Maximum Likelihood Deconvolution of Beamformed Images with SignalDependent Speckle Fluctuations from Gaussian Random Fields: With Application to Ocean Acoustic Waveguide Remote Sensing (OAWRS). Remote Sensing, 8(9), 694.

Kenny, A. J., Cato, I., Desprez, M., Fader, G., Schüttenhelm, R. T. E., \& Side, J. (2003). An overview of seabedmapping technologies in the context of marine habitat classification. ICES Journal of Marine Science: Journal du Conseil, 60(2), 411-418.

Lubis, M. Z., \& Anurogo, W. (2016). Fish stock estimation in Sikka Regency Waters, Indonesia using Single Beam Echosounder (Cruz Pro fish finder PcFF-80) with hydroacoustic survey method. Aceh Journal of Animal Science, 1(2).

Lubis, M. Z., \& Pujiyati, S. (2016). Detection Backscatter Value of Mangrove Crab (Scylla Sp.) Using Cruzpro Fishfinder Pcff-80 Hydroacoustic Instrument. J. Biosens. Bioelectron, 7(2), 2.

Lubis, M. Z., Wulandari, P. D., Mujahid, M., Hargreaves, J., \& Pant, V. (2016). Echo Processing and Identifying Surface and Bottom Layer with Simrad Ek/Ey 500. Journal of Biosensors and Bioelectronics, 7(3), 1000212.

Lubis, M. Z., Anurogo, W., Khoirunnisa, H., Irawan, S., Gustin, O., \& Roziqin, A. (2017). Using Side-Scan Sonar instrument to Characterize and map of seabed identification target in Punggur Sea of the Riau Islands, Indonesia. Journal of Geoscience, Engineering, Environment, and Technology, 2(1), 1-8.

Manik, H. M. (2011). Underwater acoustic detection and signal processing near the seabed. INTECH Open Access Publisher.

Manik, H.M. (2015). Underwater Remote Sensing of Fish and Seabed Using Acoustic Technology In Seribu Island Indonesia. International Journal of Oceans and Oceanography, 9, 77-95.

Minarto, E., Surbakti, H., Vorandra, E., Pin, T. G., Musli, M., \& Saputra, E. (2008). Kaitan Aktivitas Vulkanik dengan Distribusi Sedimen dan 
Kandungan Suspensi di Perairan Selat Sunda. Jakarta (ID): Publikasi pelayaran kebangsaan P2O LIPI.

Pujiyati, S., Hestirianoto, T., Wulandari, P. D., \& Lubis, M. Z. (2016). Fish Stock Estimation by Using the Hydroacoustic Survey Method in Sikka Regency Waters, Indonesia. J. Fisheries Livest Prod, 4(193), 2.

Simmonds, J., \& MacLennan, D. N. (2008). Fisheries acoustics: theory and practice. John Wiley \& Sons.
Hansen, R. E. (2011). Introduction to synthetic aperture sonar, in Sonar Systems. Edited by Nikolai Kolev. First Edition. InTech, Croatia. Hal. : 1-25.

Haykin, S. (1985). Array signal processing. Englewood Cliffs, NJ, Prentice-Hall, Inc., 1985, 493 p. For individual items see A8543961 to A85-43963., 1.

Urick, R. J. (1983). Principles of underwater acoustics. 